\title{
Implementasi Finite State Automata dalam Proses Registrasi Workout Plan pada Pusat Kebugaran
}

\author{
Tri Rivanie, Tika Adilah M, dan Yuris Alkhalifi
}

\begin{abstract}
Among a variety of exercise options, fitness at the fitness center is one option that can be chosen. Fitness is no longer a strenuous exercise for men only, now, women can guarantee physical fitness, lose weight and build an ideal body. Before agreeing to choose to become a member in one of the discussion areas, it is necessary to consider several things, such as the budget that must be spent with the benefits to be received. the more complete the supporting facilities at the fitness center, the more expensive the fees or costs will increase each month as a member. In addition to the available and adequate equipment, there are instructors or personal trainers who can also provide training programs, exercises, fitness exercises so that every movement that is done is not wrong and in turn results in muscle and joint injuries. The consideration is that we will choose a training program to find out what is most suitable for someone. In this paper discusses how the method of NFA State Automata type can be implemented in the registration of an exercise program (training plan) on members of a fitness center. With this applied method, users are expected to be helped in choosing an exercise program (training plan) as needed and can better consider how to choose the right and right exercise plan.
\end{abstract}

Index Terms - Workout Plan registration, Workout Plan Selection, Finite State Automata

Abstrak-- Di antara banyaknya pilihan olahraga, fitness dipusat kebugaran menjadi salah satu opsi yang dapat di pilih. Fitness bukan lagi olahraga berat hanya untuk lakilaki saja, kini perempuan pun dapat melakukannya untuk menjaga kebugaran tubuh, menurunkan berat badan dan membentuk tubuh ideal. Sebelum menetapkan pilihan untuk menjadi member disalah satu tempat kebugaran, perlu mempertimbangkan beberapa hal, seperti budget yang harus dikeluarkan dengan keuntungan yang akan diterima. semakin lengkap fasilitas penunjang di sebuah tempat fitness, maka semakin mahal tarif atau biaya yang dibayarkan setiap bulan sebagai member. Selain perlengkapan olahraga yang sudah tersedia dan memadai,

Manuscript received March 2, 2020. This work was supported in part by Ilmu Komputer, STMK Nusa Mandiri, Jakarta.

Tri Rivani, Ilmu Komputer, STMK Nusa Mandiri, email : tririvanie@gmail.com

Tika Adilam M, Ilmu Komputer, STMK Nusa Mandiri, email : tika.tam@bsi.ac.id

Yuris Alkalifi, Ilmu Komputer, STMK Nusa Mandiri, email : yuris.yak@bsi.ac.id ada instruktur atau personal trainer yang juga dapat memberikan arahan Program latihan, porsi latihan, tehnik melakukan fitness agar setiap gerakan yang dilakukan tidak salah dan malah berakibat cidera otot dan sendi. yang menjadi pertimbangan adalah kita akan memilih program pelatihan untuk mengetahui apa yang paling cocok untuk seseorang. Pada paper ini membahas tentang bagaimana metode Finite State Automata jenis NFA dapat diimplementasikan dalam Registrasi program latihan (workout plan) pada member tempat kebugaran.Dengan di terapkan metode ini, user diharapkan dapat terbantu dalam memilih program latihan (workout plan) sesuai kebutuhan dan dapat lebih memahami bagaimana proses pemilihan workout plan yang sesuai dan benar.

Kata Kunci- Registrasi Workout Plan, pemilihan Workout Plan, Finite State Automata.

\section{INTRODUCTION}

P usat Kebugaran tubuh atau fitness center merupakan tempat dimana masyarakat melakukan olah tubuh yang kemudian menghasilkan perubahan pada bagian tubuh mereka sesuai yang diinginkan. Pada pusat kebugaran biasanya seseorang akan melakukan Perencanaan program latihan (Workout Plan) yang merupakan kegiatan penentuan urutan tindakan, perkiraan biaya, sarana prasarana, penggunaan waktu, pengguaan sumber daya manusia untuk suatu program latihan di fitness center yang didasarkan atas data dengan memperhatikan prioritas yang wajar dan efisien untuk tercapainya tujuan perencanaan program latihan[1].

Beberapa tempat fitnes menyediakan seorang instruktur atau personal trainer yang membantu member dalam menjalankan fitness secara baik dan benar, membuat program untuk setiap member, memastikan para member melakukan latihan yang benar dan sesuai dengan ketentuan latihan, serta menambah pengetahuan member dalam masalah kebugaran yang mencakup masalah nutrisi dan panduan kesehatan secara umum[2]. Personal trainer dituntut harus benarbenar dapat menentukan program yang paling sesuai dengan kebutuhan member demi mencapai hasil yang diharapkan. oleh karena itu dirancang sebuah aplikasi yang membantu pemilihan workout Plan yang tepat 
untuk member sesuai Tipe Tubuhnya. Pada penelitian ini penerapan automata digunakan untuk mengenal dan menangkap pola dalam proses aplikasi bantu ini.

Finite State Automata(FSA) jenis NFA merupakan model yang digunakan untuk merancang aplikasi yang dapat membantu dalam workout plan ini. Teori bahasa bertindak sebagai sarana komunikasi baik sesama manusia ataupun antara manusia dan mesin. Sedangkan teori automata merupakan teori mengenai mesin-mesin abstrak, dan berkaitan erat dengan teori bahasa formal. Teori bahasa dan automata sangat berguna untuk pengembangan ilmu komputer lebih lanjut baik dalam perangkat keras (hardware), dan perangkat lunak (software)[3].

\section{TINJAUAN PUSTAKA}

\section{A. Finite State Automata}

Finite State Automata/outomata berhingga state, selanjutnya disebut sebagai FSA yaitu suatu model matematika dari suatu sistem yang menerima input dan output diskrit. FSA merupakan mesin otomata dari bahas regular [4]. Suatu FSA memiliki state yang banyaknya berhingga dan dapat berpindah-pindah dari suatu state ke state lain[5]. FSA tidak memiliki tempat penyimpanan atau memory, hanya bisa mengingat state terkini[6].

Perubahan state ini dinyatakan oleh fungsi transisi. FSA tidak memiliki tempat penyimpanan, sehingga kemampuan 'mengingatnya' terbatas, hanya bisa mengingat state yang terkini. Contoh FSA antara lain elevator, text editor, analisa leksikal, protokol komunikasi jaringan dan pencek parity. FSA berdasar pada pendefinisian kemampuan berubah state-statenya bisa dibagi menjadi Deterministic Finite Automata (DFA) dan Non-deterministic Finite Automata (NFA).

Secara formal FSA dinyatakan oleh 5 tupel atau $\mathrm{M}=$ $(\mathrm{Q}, \Sigma, \delta, \mathrm{S}, \mathrm{F})$ dimana:

$\mathrm{Q}=$ himpunan state/kedudukan

$\Sigma=$ himpunan simbol input/masukan/abjad

$\delta=$ fungsi transisi

$\mathrm{S}=$ state awal/kedudukan awal (initial state), $\mathrm{S} \in \mathrm{Q}$

$\mathrm{F}=$ himpunan state akhir, $\mathrm{F} \cap \mathrm{Q}$ (jumlah state akhir pada suatu FSA bisa lebih dari satu)

\section{B. Non-deterministic Finite Automata}

Sebuah Nondeterministic Finite Automaton (NFA) merupakan jenis finite state machine (FSM) dimana salah satu next state tidak sepenuhnya ditentukan oleh current state ataupun input. Himpunan dari possible next states menyatakan bahwa automata dapat berpindah dari state tertentu (qa) ke state yang lain (qb) sebagai tanggapan terhadap suatu input $(\alpha)$. Dalam NFA, jumlah start state dan transisi untuk setiap anggota himpunan input $(\Sigma)$ tidak harus tepat satu[7]. Notasi bahasa formal dari NFA adalah sebagai berikut:

$$
\mathrm{A}=\{\mathrm{Q}, \Sigma, \delta, \mathrm{q} 0, \mathrm{~F}\}
$$

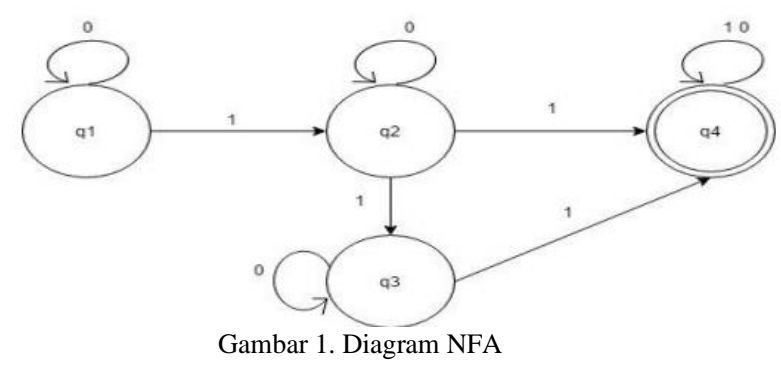

Dari diagram Gambar 1, kita bisa melihat bahwa tuplenya sebagaiberikut:

$\mathrm{Q}=\{\mathrm{q} 1, \mathrm{q} 2, \mathrm{q} 3, \mathrm{q} 4\}$

$\Sigma=\{0,1\}$

$\delta=$ Fungsi transisi

$\delta(\mathrm{q} 1,0)=\mathrm{q} 2, \delta(\mathrm{q} 1,1)=\mathrm{q} 2, \delta(\mathrm{q} 2,0)=\mathrm{q} 2$

$\delta(\mathrm{q} 2,1)=(\mathrm{q} 3, \mathrm{q} 4), \delta(\mathrm{q} 3,0)=\mathrm{q} 3, \delta(\mathrm{q} 3,1)=\mathrm{q} 4$,

$\delta(\mathrm{q} 4,0)=\mathrm{q} 4, \delta(\mathrm{q} 4,1)=\mathrm{q} 4$

$\mathrm{S}=\{\mathrm{q} 1\}$

$F=\{q 4\}$

Dari fungsi transisi tersebut maka tabel transisinya yaitu:

Tabel 1. Tabel Transisi

\begin{tabular}{ccc}
\hline \multicolumn{2}{l}{ Tabel 1. Tabel Transisi } \\
$\delta$ & 0 & 1 \\
\hline $\mathrm{q} 1$ & $\mathrm{q} 1$ & $\mathrm{q} 1$ \\
$\mathrm{q} 2$ & $\mathrm{q} 3$ & $(\mathrm{q} 3, \mathrm{q} 4)$ \\
$\mathrm{q} 3$ & $\mathrm{q} 3$ & $\mathrm{q} 4$ \\
$\mathrm{q} 4$ & $\mathrm{q} 4$ & $\mathrm{q} 4$ \\
\hline \hline
\end{tabular}

\section{METODE PENELITIAN}

Sistem dirancang dengan menggunakan flowchart. Bagan ini menjelaskan tentang gambaran umum pada aplikasi bantu Registrasi Workout plan. Untuk jelasnya dapat dilihat di Aplikasi registrasi Workout Plan yang dirancang untuk merekomendasikan Program yang akan diambil oleh member sehingga apabila member ingin mengambil suatu Program workout plan maka sistem akan melakukan validasi terhadap jenis tipe tubuh, apakah sudah memenuhi syarat atau tidak. Pada flowchart aplikasi ini dapat dijelaskan sebagai berikut:

1. Member melakukan pengisian Biodata pada form workout plan Jenis kelamin,berat badan,tinggi badan,umur,cek kadar lemak,riwayat penyakit,alergi makanan,menuliskan tipe tubuh,body goal.

2. Member menentukan memilih Workout Plannya yang akan diambil.

3. Sistem akan merekomendasikan Workout Plan yang diambil, memverifikasi apakah sudah sesuai dengan data dan kriteria bentuk tubuh untuk menentukan goal dari workout plan yang akan diambil. Sistem akan menghitung BMR dan BMI (Body Mass Index)

4. BMR (Basal Metsbolic Rate) adalah kebutuhan kalori yang dibutuhkan untuk melakukan aktivitas basal[8]. BMR Tiap orang berbeda-beda 
tergantung pada usia, jenis kelamin, berat badan dan tinggi badan.dan rumus BMR ini dibedakan antara Pria dan Wanita :

a. $\quad$ BMR Pria $=66+(13,7 \times$ berat badan $)+$ (5x tinggi badan $)-(6,8 \times$ usia $)$

b. BMR Wanita $=655+(9,6 \times$ berat badan $)+$ (1,8x tinggi badan $)-(4,7 \times$ usia $)$

Keterangan:

Berat badan dalam kilogram $(\mathrm{kg})$

Tinggi badan dalam sentimeter $(\mathrm{cm})$

BMI (Body Mass Index) atau "Indeks massa tubuh (IMT) adalah parameter yang ditetapkan oleh WHO (Badan Kesehatan Dunia) sebagai perbandingan berat badan dengan kuadrat tinggi badan[9].

Indeks massa tubuh adalah metrik standar yang digunakan untuk menentukan siapa saja yang masuk dalam golongan berat badan sehat dan tidak sehat[10], adapun rumusnya sebagai berikut :

$$
\mathrm{BMI}=\frac{(\text { Weight } \text { in Kilograms })}{\text { height in meter }}
$$

Tabel 2.vTabel Index Masa Tubuh (IMT)

\begin{tabular}{cc}
\hline \hline Nilai IMT & Artinya \\
\hline 18,4 ke bawah & Berat Badan Kurang \\
$18,5-24,9$ & Berat Badan Ideal \\
$25-29,9$ & Berat Badan Lebih \\
$30-39,9$ & Gemuk \\
40 ke atas & Sangat Gemuk \\
\hline \hline
\end{tabular}

Kemudian kita bisa memasukan nilai IMT untuk mengetahui kadar lemak Tubuh.berikut adalah rumus prediksi presentase lemak di dalam tubuh:

Laki-laki : $(1,20 \mathrm{x}$ IMT $)+(0,23 \times$ Usia $)-10,8-5,4$

Wanita : $(1,20 \mathrm{x}$ IMT $)+(0,23 \mathrm{x}$ Usia $)-5,4$

5. Sistem akan menampilkan laporan hasil dari olahan data dan Workout Plan Program yang cocok untuk tipe tubuh tersebut. Bila di tolak maka member akan berlatih tanpa workout plan dan bimbingan personal trainer dan bila diterima member maka akan melanjutkan pada jadwal sesi latihan workout Plan Program tersebut.

6. Personal Trainer akan membuat laporan progress hasil latihan dan perkembangan setiap harinya untuk perkembangan program lanjutan yang akan diambil setelah menyelesaikan program pertama.
Adapun isi dari workout plan meliputi

2.1 Skema Sistem Aplikasi secara keseluruhan

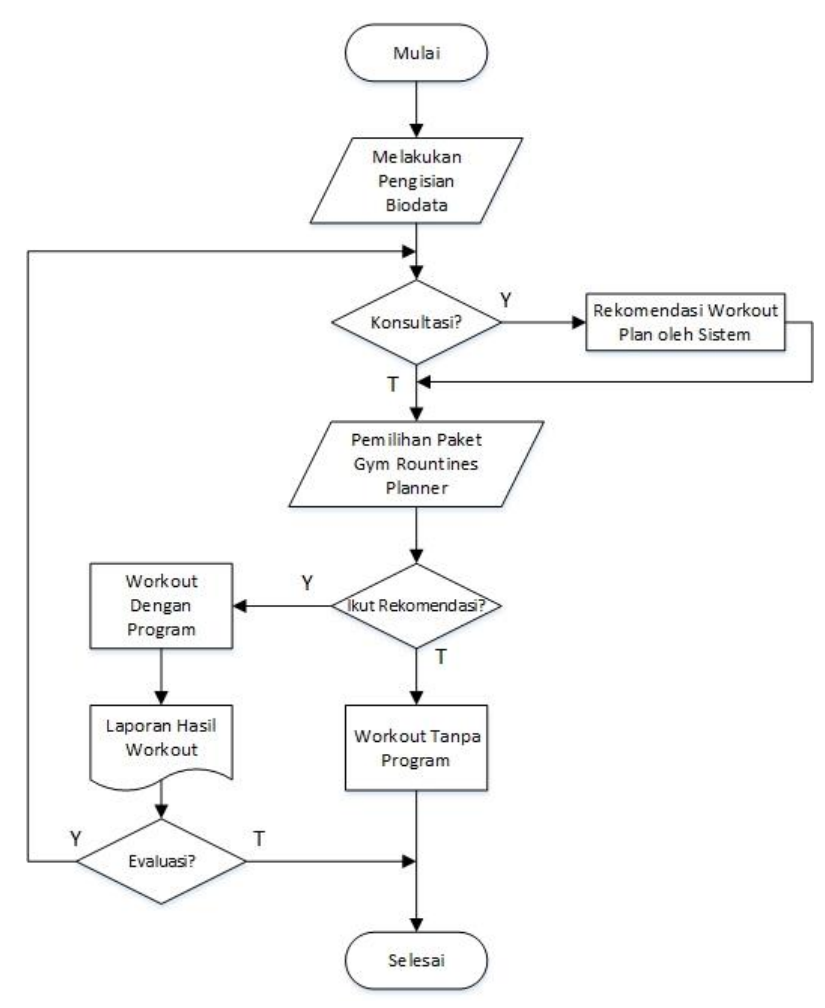

Gambar 1. Flowchart Workout Plan

\subsection{Skema Finite State Automata}

Metode yang digunakan dalam perancangan aplikasi bantu ini yaitu menggunakan FSA. Metode yang digunakan yaitu dengan menggunakan finite state, yang mana jika diambil contoh kasus sebagai berikut:

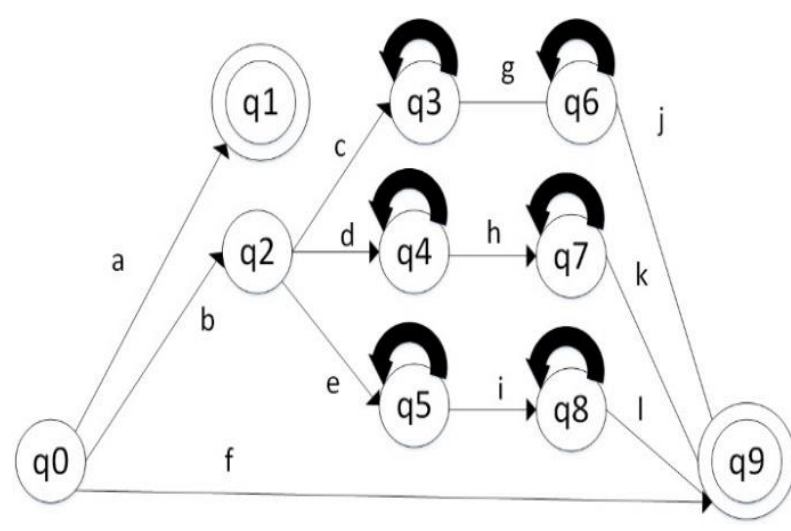

Gambar 2. Metode FSA Workout Plan

Keterangan:

$\mathrm{Q} 0=$ Status Awal

Q1 = Mengikuti hanya sesi Latihan harian

Q2 = Registrasi/Konsultasi sebagai member bulanan

Q3 = Terdaftar sebagai Member dengan kategori Tubuh 


\begin{tabular}{|c|c|c|}
\hline 4 & & $\begin{array}{l}\text { Terdaftar sebagai Member } \\
\text { kategori Tubuh Endomorph }\end{array}$ \\
\hline 25 & $=$ & $\begin{array}{l}\text { Terdaftar sebagai Member } \\
\text { kategori Tubuh Mesomorph }\end{array}$ \\
\hline & $=$ & $\begin{array}{l}\text { Mendapatkan Bulking Workout Plan } \\
\text { Program }\end{array}$ \\
\hline & $=$ & $\begin{array}{l}\text { Mendapatkan Fatloss/Weightlos } \\
\text { Workout Plan Program }\end{array}$ \\
\hline & $=$ & $\begin{array}{l}\text { Mendapatkan Kombinasi Workout Plan } \\
\text { Program }\end{array}$ \\
\hline & $=$ & Sesi Latihan \\
\hline & & harian \\
\hline & & strasi pendaftaran sebagai member \\
\hline & & $\begin{array}{l}\text { Sistem memferifikasi Tubuh masu } \\
\text { dalam kategori Ectomorph }\end{array}$ \\
\hline & & $\begin{array}{l}\text { Sistem memferifikasi Tubuh masul } \\
\text { dalam kategori Endomorph }\end{array}$ \\
\hline & & $\begin{array}{l}\text { Sistem memferifikasi Tubuh masul } \\
\text { dalam kategori Mesomorph }\end{array}$ \\
\hline $\mathrm{F}$ & & Member bulanan tanpa workout plan \\
\hline $\mathrm{G}$ & $=$ & $\begin{array}{l}\text { Member mengambil Bulking workou } \\
\text { Plan Program }\end{array}$ \\
\hline $\mathrm{H}$ & $=$ & $\begin{array}{l}\text { Member mengambil Fatloss/weightlos } \\
\text { workout Plan Program }\end{array}$ \\
\hline I & $=$ & $\begin{array}{l}\text { Member mengambil Kombinasi workou } \\
\text { Plan Program }\end{array}$ \\
\hline J & & Member melakukan sesi program Bulkin \\
\hline & & $\begin{array}{l}\text { Workout Plan Program } \text { Bersam } \\
\text { Personal Trainer }\end{array}$ \\
\hline K & $=$ & $\begin{array}{l}\text { Member melakukan sesi program } \\
\text { Fatloss/weightloss } \quad \text { Workout Plan } \\
\text { Program Bersama Personal Trainer }\end{array}$ \\
\hline $\mathrm{L}$ & $=$ & $\begin{array}{lrrr}\text { Member melakukan } & \text { sesi } & \text { program } \\
\text { Kombinasi } & \text { Workout } & \text { Plan } & \text { Program }\end{array}$ \\
\hline
\end{tabular}

\section{HASIL DAN PEMBAHASAN}

Program yang dibuat merupakan program berbasis desktop. Dengan tampilan yang sederhana, sehingga memudahkan user dalam menggunakanya. Form awal pada aplikasi ini berisikan tampilan daftar baru dan login, login diperuntukan untuk member yang sudah terdaftar di tempat kebugaran,daftar baru dimana user akan menginput data member baru yang mendaftar,data yang diinput tersebut ini akan disimpan oleh system kemudian user menawarkan apakah member tersebut bersedia mengikuti workout plan. Jika member bersedia, calon member akan mendapat beberapa pemeriksaan secara khusus untuk melengkapi data tambahan seperti alergi makanan atau riwayat penyakit turunan dan user akan di tampilkan ulang data member baru atau calon member tersebut yang kemudian otomatis system akan merancang workout plan untuk calon member tersebut dan memberikan laporan print out kepada personal trainer untuk mendapatkan sesi latihan Khusus.

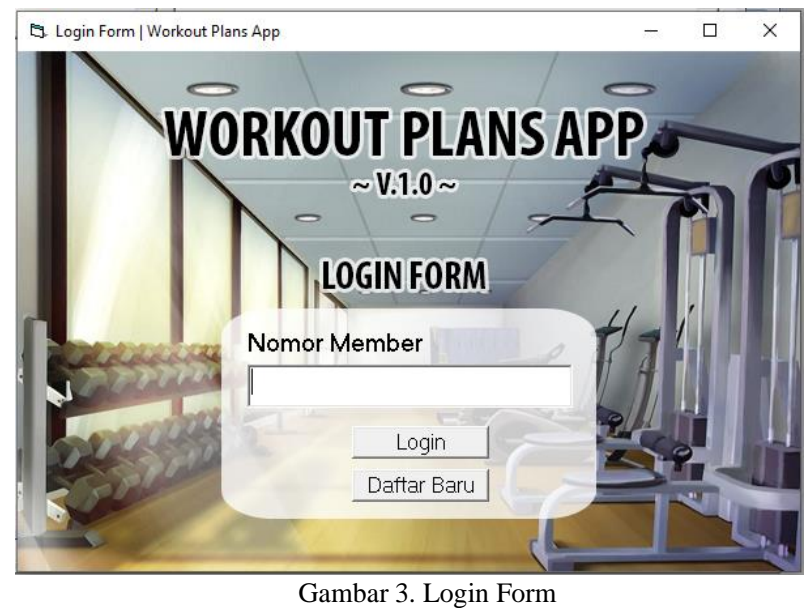

Pada login form, apabila member sudah dafttar sebelumnya, admin menginput nomor member kemudian klik login, namun apabila member belum daftar, maka admin akan membuat data member baru dengan mengklik tombol Daftar Baru.

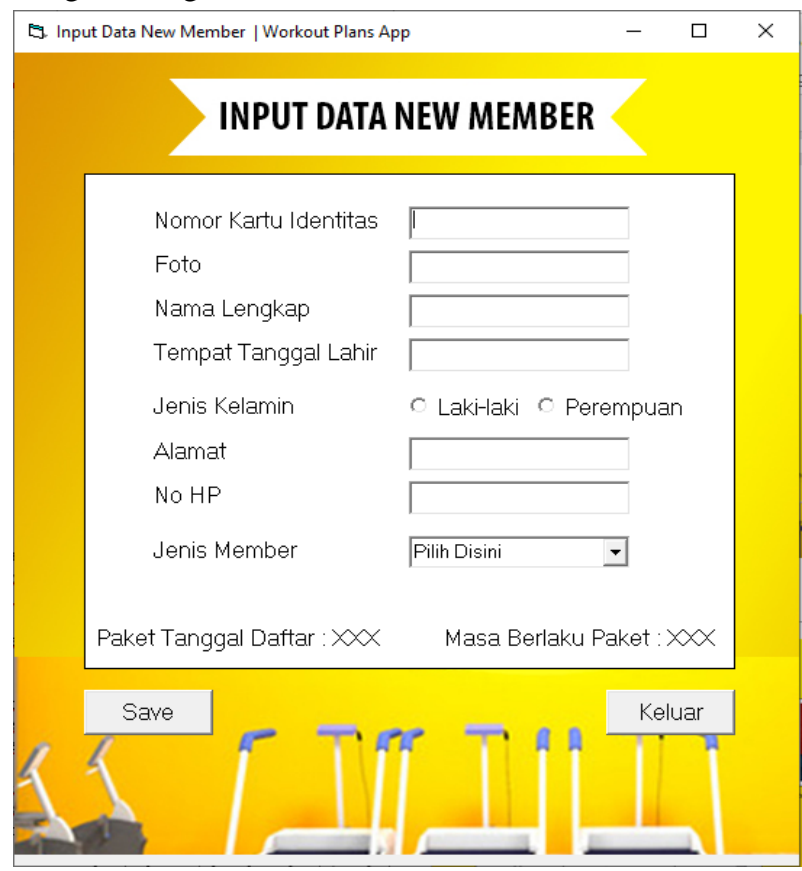

Gambar 4. Input Data New Member

Pada input data member baru, admin akan mengisi formulir member mulai dari nomor kartu identitas, foto hingga jenis member. Setelah benar maka simpan dengan mengklik tombol save. Kemudian bisa langsung login dengan nomor member.

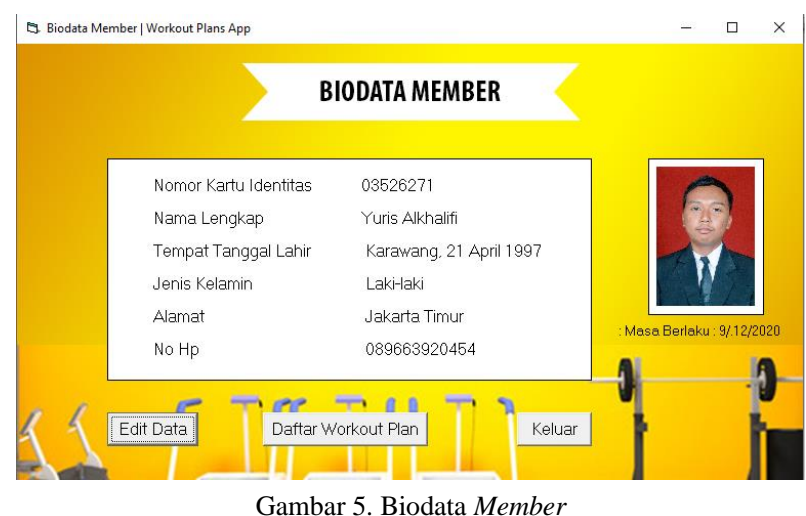


Jika sudah login, maka tampil seperti tampilan seperti gambar 5 diatas. Dalam biodata member bisa akan ditampilkan biodata member yang sudah login antara lain: nomor kartu identitas, nnama lengkap, tempat tanggal lahir, jenis kelamin, alamat dan nomor hp. Apabila ada kesalahan data member bisa mengklik tombol Edit Data. Namun jika member menyatakan ingin daftar workout plan maka admin mengklik tombol Daftar Workout Plan.

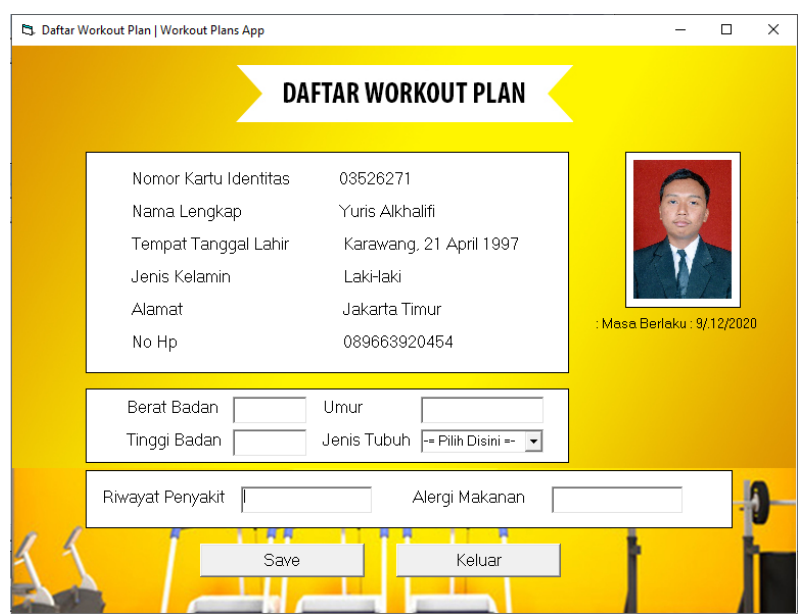

Gambar 6. Daftar Workout Plan

Apabila member akan mendaftar workout plan maka aplikasi akan tampil seperti gambar 6. Dalam menu daftar workout plan, Admin akan mengisi formulir kembali yakni berat badan, tinggi badan, umur, jenis tubuh, riwayat penyakit dan alergi makanan. Jika sudah benar, langkah selanjutnya menyimpan data workout member tersebut dengan mengklik tombol save.

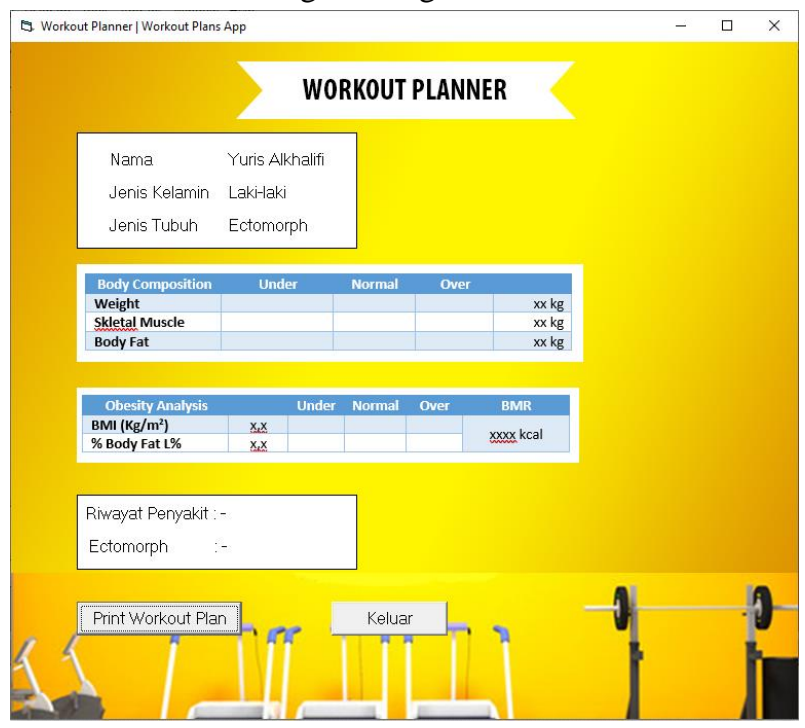

Gambar 7.Workout Planner

Setelah admin mengisi formulir dalam daftar workout plan, selanjutnya program akan menganalisa dan menampilkan tipe badan apa yang dimiliki member. Apakah berat bobotnya dibawah rata-rata, atau normal, atau melebihi. Begitupun dengan Otot dan Lemak Tubuh. Lalu programpun menampilkan hasil analisa BMI dan BMR. Apabila member ingin tahu hasilnya dalam bentuk kertas, maka admin bisa mengklik Print Workout Plan.

\section{V.KESIMPULAN}

Finite state automata berjenis NFA sangat membantu dalam menentukan seseorang untuk menentukan pilihan program workout plan dan memberi gambaran system yang cukup detail dalam menentukan program latihan yang tepat. dengan menggunakan pemodelan finite state automata jenis NFA pemodelan lebih cepat dan terstruktur. Hubungan dan transisi antar fungsional dalam aplikasi dengan mudah dapat didefinisikan dengan transisi antar state, sehingga dalam proses pengembangan tidak terjadi kesalahan pendefinisian hubungan antar fungsional. Penentuan workout Plan disusun oleh system ditempatkan menggunakan state yang telah diurutkan berdasarkan ketentuan dari masing-masing kriteria bentuk tubuh. Dengan Program ini, member diharapkan dapat terbantu dan mengetahui workout plan yang benar dan sesuai dengan metabolism dan bentuk tubuhnya masing-masing.

\section{REFERENCES}

[1] Kurnianto, A. N., \& Rismayanthi, C. (2015). PROGRAM LATIHAN DAN JASA LAYANAN YANG DIBERIKAN PADA MEMBERS FITNESS DI YOGYAKARTA. XIV(1).

[2] Shakuntala, F. (2011). PERSONAL TRAINER CELEBRITY FITNESS LA PIAZZA.

[3] Adenis, P., Mukherjee, K., \& Ray, A. (2011). State splitting and state merging in probabilistic finite state automata. Proceedings of the American Control Conference, 5145-5150. https://doi.org/10.1109/acc.2011.5990861

[4] Widyasari. (2011). Telaah Teoritis Finite State Automata Dengan Pengujian Hasil Pada Mesin Otomata. Jurnal Ilmiah SISFOTENIKA, 1(1), 59-67

[5] Farmanbar, A., Firouzi, S., Park, S. J., Nakai, K., Uchimaru, K., \& Watanabe, T. (2017). Multidisciplinary insight into clonal expansion of HTLV-1-infected cells in adult T-cell leukemia via modeling by deterministic finite automata coupled with high-throughput sequencing. BMC Medical Genomics, 10(1), 1-12. https://doi.org/10.1186/s12920-016-0241-2

[6] W., R. A., Tolle, H., \& Setyawati, O. (2016). Pengembangan Aplikasi Text-to-Speech Bahasa Indonesia Menggunakan Metode Finite State Automata Berbasis Android. Jurnal Nasional Teknik Elektro Dan Teknologi Informasi (JNTETI), 5(1). https://doi.org/10.22146/jnteti.v5i1.179

[7] Sahrul, Karimah, F., Muhazabah, A., Prasetyo, D. A., Yunita, A., \& Zahra, L. N. (2018). Pengembangan Aplikasi Permainan “ Pilah Sampa H " Menggunakan Pemodelan Finite State Machine. Teknologia, 1(1), 37-44.

[8] Hellosehat.com. (2019). Cara Menghitung Indeks Massa Tubuh (Body Mass Index). In https://hellosehat.com/hidup-sehat/caramenghitung-indeks-massa-tubuh-body-mass-indeks/

[9] Situmorang, M. (2015). Penentuan Indeks Massa Tubuh (IMT) melalui Pengukuran Berat dan Tinggi Badan Berbasis MikrokontrolerAT89S51 dan PC. Jurnal Teori Dan Aplikasi Fisika, 03(02), 102-110.

[10] Hellosehat.com. (2019). Cara Menghitung BMR (Basal Metsbolic Rate). In https://hellosehat.com/hidup-sehat/caramenghitung-indeks-massa-tubuh-body-mass-indeks/ 